Lentera Pustaka 4 (1): 39-47, 2018

Copyright (C2018, ISSN: 2302-4666 print/ 2540-9638 online

Available Online at: http://ejournal.undip.ac.id/index.php/lpustaka

\title{
SUBJ ECT GUIDE: PROFESIONALISME PUSTAKAWAN DALAM BIMBINGAN INFORMASI DAN PENERAPANNYA
}

\author{
Okky Rizkyantha ${ }^{\left.1^{*}\right)}$ \\ ${ }^{1}$ Departemen Interdisciplinary Islamic Studies, Konsentrasi Ilmu Perpustakaan, Fakultas Pascasarjana UIN \\ Sunan Kalijaga Yogyakarta \\ ${ }^{*}$ Korespodensi: orizkyantha@gmail.com
}

\begin{abstract}
[Title: Subject Guide: Librarian Profesionalism in Information Guiding and The Implementation.] Librarian professionalism is not simply to be seen from how long he worked as a librarian and what his education level is. The important things must be seen from the librarian professionalism are the real competence of librarian and his creativity can provide convenience to the user in obtaining information. This article seeks to provide insight into librarian professionalism through subject guides, and the role of librarian in tracking of information for public. This research used literature method. Data collection techniques used the analysis of books, websites, and scientific papers related to the title. The result shows that (1) librarian as an information consultant gives information guidance to the user in finding the needed information (2) Subject guide as the creativity of librarian in providing service and a proof of librarian profesionalism as well.
\end{abstract}

Keywords: subject guide; information consultant; librarian professionalism

\begin{abstract}
Abstrak
Profesionalisme pustakawan tidak hanya dilihat seberapa lama ia bekerja sebagai seorang pustakawan maupun dari jenjang pendidikannya. Yang perlu dilihat dari profesionalisme pustakawan adalah kompetensi pustakawan dan kreativitas yang nyata dapat memberikan kemudahan kepada pemustaka dalam mendapatkan informasi. Artikel ini berusaha untuk memberikan pandangan mengenai profesionalisme pustakawan melalui subject guide, dan peran pustakawan dalam penelusuran informasi bagi masyarakat. Penelitian ini menggunakan metode penelitian studi pustaka atau literatur. Teknik pengumpulan data yang digunakan melalui analisa buku, website, dan karya ilmiah yang terkait dengan judul. Hasil menunjukkan bahwa (1) pustakwan sebagai konsultan informasi bagi pemustaka memberikan bimbingan informasi kepada pemustaka dalam mencari informasi yang dibutuhkan (2) Subject guide sebagai bentuk kreativitas pustakawan dalam memberikan pelayanan serta sebagai alat pembuktian profesionalisme pustakawan.
\end{abstract}

Kata kunci: subject guide; konsultan informasi; profesionalisme pustakawan

\section{Pendahuluan}

Profesionalisme pustakawan merupakan topik yang menarik untuk dibahas. Hal ini terkait dengan organisasi dimana pustakawan itu bekerja, yaitu perpustakaan. Perpustakaan merupakan organisasi yang dinamis dan terus berkembang, sehingga membutuhkan sumber daya manusia yang handal di bidangnya. Pustakawan sebagai sumber daya manusia yang menggerakkan roda kemajuan perpustakaan mempunyai tugas sebagai agen informasi kepada masyarakat. Kepustakawanan dan masyarakat merupakan dua hal yang harus disadari oleh setiap pustakawan dalam menjalankan tugasnya. Kepustakawanan mengambil bagian dari keterampilan pustakawan dalam mengelola perpustakaan, sedangkan masyarakat sebagai objek kajian yang perlu dipelajari oleh pustakawan dalam memberikan layanannya. Kedua materi tersebut perlu dipahami oleh pustakawan secara holistik dalam rangka mencapai kata profesionalisme pustakawan. Pustakawan sebagai pengaju 
proposal secara jelas menunjukkan benang merah antara berkembangnya perpustakaan dan terpenuhinya kebutuhan informasi masyarakat (Suwarno, 2013: 57).

Profesionalisme pustakawan perlu dikaji lebih lanjut sebagai kesadaran diri akan tanggung jawab pustakawan terhadap informasi dan pengguna. Informasi yang tak terelakkan kedinamisannya dan masyarakat yang selalu tumbuh dan mempunyai keberagaman kebutuhan informasi menjadi tantangan tersendiri bagi pustakawan dalam mencapai profesionalismenya. Seiring dengan perkembangan keduanya, pustakawan harus dapat menyesuaikan diri sebagai bentuk keterbukaan diri terhadap perubahan dan kemauan diri untuk melayani pengguna secara optimal. Profesionalisme adalah sesuatu kesadaran dan kemauan diri yang timbul dari dalam untuk berusaha menjaga dan memiliki sesuatu dengan tetap berusaha untuk mencapai optimalitas. Untuk dapat melihat profesionalisme seorang pustakawan, kita dapat melihatnya melalui pelaksanaan kegiatan perpustakaan yang dilakukannya, yang mana pelaksanaan kegiatan perpustakaan yang dilakukan harus didasarkan pada keahlian, rasa tanggung jawab dan pengabdian. Pustakawan yang memiliki jiwa profesional terhadap pekerjaannya akan selalu mengembangkan kemampuan dan keahliannya untuk memberikan hasil kerja yang lebih bermutu dan sumbangan yang besar kepada pengguna perpustakaan maupun masyarakat secara umum.

Kiranya cukup jelas bahwa setiap pribadi mempunyai kebutuhan terhadap informasi. Berpikir tentang bagaimana caranya meningkatkan pengetahuan yang dimilikinya, maka ia mulai berpikir tentang upaya mencari informasi untuk mencapai tujuan tersebut, termasuk dengan cara membaca dan menelusuri berbagai bahan bacaan yang terpikir banyak kaitannya dengan masalah yang dipikirkannya itu (Yusuf, 2010: 82). Perpustakaan sebagai sumber informasi menjadi pilihan masyarakat dalam menyelesaikan masalah informasinya. Namun terkadang informasi yang disediakan sulit untuk ditemukan bahkan kadang tidak memberikan alternatif lain untuk mendapatkan informasi tersebut. Kebutuhan informasi masyarakat yang variatif tersebut memaksa pustakawan untuk lebih kreatif dan inovatif dalam memberikan informasi, salah satunya dengan mengemas ulang informasi dan memberikan akses ke informasi tersebut.

Subject guide hadir sebagai media yang menjembatani antara kemauan diri pustakawan untuk melayani secara optimal dengan masyarakat yang membutuhkan informasi secara lengkap dan cepat. Nurgahayu $(2016 ; 1)$ mengatakan bahwa Subject Guide adalah suatu panduan untuk pemustaka dalam penelusuran informasi yang sudah dikategorikan berdasarkan kekhususan subject. Subject guide mempunyai fungsi sama seperti pathfinder, yaitu memberikan informasi kepada pemustaka namun mempunyai perbedaan pada spesifik subject yang disajikannya. Panduan ini dimanfaatkan untuk memenuhi kebutuhan informasi pemustaka yang menginginkan hasil penelusuran secara cepat, tepat, dan mudah (Nugrahayu, 2016: 1). Beberapa perpustakaan perguruan tinggi di Indonesia telah menerapkan subject guide sebagai bentuk kesadaran diri terhadap layanan penelusuran informasi. Dalam artikel ini penulis berusaha untuk memberikan pandangan peran subject guide dalam 
penelusuran informasi serta peran pustakawan sebagai bentuk profesionalisme dalam penelusuran informasi dan pelayanan informasi kepada masyarakat. Penulis juga berusaha memfokuskankajian terhadap pandangan pustakawan dalam menunjukkan profesionalismenya melalui subject guide dan keluwesan pustakawan dalam mengembangkan kompetensinya sebagai wujud profesionalisme.

\section{Tinjauan Pustaka}

Qalyubi (2007: 236) mengatakan bahwa istilah pathfinder merupakan terjamahan dari istilah bahasa inggris library pathfinder yang berarti panduan pustaka. Penggagas pathfinder adalah Charles H. Stevens,seorang associate director dari Library Development, Project Intrex, Massachusets Institut of Technology (MIT), Amerika Serikat. Gagasan tersebut kemudian dikembangkan oleh staf dari Model Library Project, Project Intex (Qalyubi, 2007: 236) . Menurut Canfield (1972) bahwa pathfinder adalah checklist pengantar untuk subjek-subjek tertentu dan didesain untuk membimbing para pemustaka perpustakaan pada tahapan awal penelusuran literatur. Tujuan Pathfinder adalah untuk membantu para pemustaka yang hendak mulai mencari informasi mengenai masalah ilmiah khusus, tetapi masih kurang memahami atau hanya secara umum mengenal sumber informasi di Perpustakaan. Dengan demikian panduan pustaka merupakan chechlist pengantar untuk subjek-subjek tertentu, dan didesain untuk membimbing para pemakai pada tahap awal penelusuran literature. Jadi panduan perpustakaan tidak dimaksudkan sebagai bibliografi yang lengkap dan luas (Qalyubi, 2007: 236). Lebih lanjut lagi media penelusuran yang disediakan oleh perpustakaan adalah subject guide. Subject Guide merupakan salah satu media penulusuran informasi yangmencakup informasi terseleksi mengenai suatu ilmu yang dikategorikan menurutsubyek ilmu pengetahuan. Subject Guide memiliki fungsi untuk menunjukkan letaksuatu koleksi atau informasi yang terdapat di perpustakaan. Perbedaan subject guide dan pathfinder adalah pada kegunaan dan spesifikasinya. Pathfinder digunakan untuk memberikan panduan kepada pemustaka terkait koleksi perpustakaan secara umum, sedangkan subject guide memberikan panduan kepada pemustaka terkait subject tertentu yang telah disusun sedemikian rupa untuk memudahkan pencarian informasi pada bidang tertentu.

Selanjutnya Wiji Suwarno (2013: 56) mengatakan bahwa bukan merupakan suatu kerahasiaan jika untuk menjadi seorang yang profesional harus memiliki profesi tertentu yang diperoleh melalui sebuah proses pendidikan maupun pelatihan yang khusus, dan di samping itu pula terdapat unsur semangat pengabdian di dalam melaksanakan suatu kegiatan kerja. Profesi merupakan kelompok lapangan kerja yang khusus melaksanakan kegiatan yang memerlukan keterampilan dan keahlian tinggi guna memenuhi kebutuhan yang rumit dari manusia, di dalamnya pemakaian dengan cara yang benar akan keterampilan dan keahlian tinggi hanya dapat dicapai dengan dimilikinya penguasaan pengetahuan dengan ruang lingkup yang luas, mencakup sifat manusia, kecenderungan sejarah, dan lingkungan hidupnya, serta adanya disiplin etika yang dikembangkan dan diterapkan oleh kelompok anggota yang menyandang profesi tersebut. Depdikbud(1989) merinci sikap yang meliputilima komponen, yaitu (1) sikapmementingkan kepuasan pemakai, (2) sikap efisien danekonomis, (3) sikap 
disiplin, (4) sikap selalu berupaya meningkatkan serta mengembangkanpengetahuan dan keterampilan di bidangnya, serta (5) sikap senantiasamemelihara rasakesejawatan dengan teman-teman yang seprofesi. Pustakawan sendiri merupakan sumber daya manusia yang melakukan profesionalisme di perpustakaan. Perpustakaan yang merupakan organisasi yang memberikan layanan kepada masyarakat membutuhkan profesioslisme pustakawan dalam menjaga stabilitas dan eksistensi perpustakaan. Pustakawan seharusnya merupakan tenaga fungsional yang statusnya tidak berbeda dengan tenaga profesional lainnya. Oleh karena itu masa depan seorang pustakawan harus mampu memberikan jasa dan memberikan pelayanan yang memuaskan pelanggannya (Suwarno, 2013: 88).

\section{Metode Penelitian}

Penelitian ini menggunakan metode studi literatur. Zed (2008) mengatakan bahwa studi literatur adalah metode pemecahan masalah dengan penilaian mendalam terhadap masalah yang telah dirumuskan dengan menggunakan bantuan literatur terkait.Peneliti menggunakan teknik pengumpulan data dengan menganalisa buku, website, dan karya ilmiah yang terkait dengan judul. Selanjutnya, metode analisis data adalah deskripsi kualitatif yang menjelaskan aspek-aspek yang dipelajari secara mendalam. Artikel ini berusaha untuk memberikan pandangan bahwa subject guide merupakan bentuk upaya rill pustakawan dalam memberikan layanan yang profesional bagi pemustaka dan masyarakat secara umum.

\section{Pembahasan}

\section{Pustakawan menjadi Konsultan Informasi}

Menjadi konsultan informasi adalah gerakan kesadaran pustakawan terhadap profesionalisme kerja. Konsultan informasi juga sebagai bentuk pendekatan kritikal terhadap perannya dalam informasi ilmiah. Bukan hanya sebagai praktisi, namun juga sebagai edukator yang sekarang dibutuhkan dalam menyelesaikan masalah informasi masyarakat.Dengan mengajukan diri sebagai konsultan informasi, pustakawan mendapatkan posisi penting dan menjadi salah satu pertimbangan pemustaka dalam mendapatkan informasi yang dibutuhkan. Selain itu hal tersebut juga sebagai bentuk pengemban kompetensi personal dalam usaha untuk memberikan kontribusi terhadap perpustakaan. Kompetensi personal yaitu keterampilan, perilaku yang dimiliki pustakawan agar dapat bekerja secara efektif sebagai komunikator,meningkatkan kemampuandan dapat bertahan terhadap berubahan dan perkembangan jaman (Siregar, 2016: 221-222).

Dalam prakteknya, pustakawan melayani pemustaka yang mempunyai kebutuhan informasi bervariatif. Pencari informasi ilmiah seperti dosen, mahasiswa, dan masyarakat akademik lainnya menjadi perhatian khusus terkait pelayanan perpustakaan terhadap penggunaan informasi ilmiah. Pemustaka termasuk kadang sulit untuk menemukan referensi yang dibutuhkannya dalam menyelesaikan masalah ilmiahnya. Pustakawan tidak hanya hadir sebagai penyedia sumber tapi juga sebagai penyelesai masalah informasi. Bimbingan kepada pemustaka terkait informasi ilmiah perlu 
dilakukan, sehingga pustakawan hadir sebagai konsultan informasi ilmiah. Bentuk pendekatan yang dapat dilakukan pustakawan sebagai konsultan informasi adalah dengan menerapkan konsep Liason Librarian. Menurut Glossop dalam Puspitasari (2015) bahwa liason librarianact as a link between the library and itsclients. Dalam konsep ini seorang pustakawan berperan untuk (1) menjawab pertanyaan ataukonsultasi. Liason librarian menjawab semua pertanyaan pemustaka yang berkaitan dengan perpustakaan. Liason librarian bahkan dapat memberikan masukan mengenai trending topic/topik penelitian bidang tertentu. Untuk itu perlu ditetapkan masing-masing liason librarian yang fokus pada suatu subjek. (2) mencari informasi mengenaiusulan pembelian buku. Liason librarian adalah seseorang yang sering berhubungan dengan fakultas tertentu sesuai dengan subjek yang ada. (3) Interlibrary loan. Liason librarian membantu pemustaka untuk meminjam buku dari perpustakaan lain. (4) membuat subject guide.Setiap liason librarian membuat subject guide dalam bidang tertentu. Subject guide adalah suatu panduan bagi pengguna untuk menunjukkan atau mengarahkan pengguna dalampenelusuran informasi, khususnya yang berkaitan dengan subjek tertentu.

Untuk memberikan konsultasi dan bimbingan kepada pemustaka, pustakawan harus mengetahui secara holistik permasalahan utama informasi pemustaka dan selanjutnya diselesaikan dengan menggunakan sumber daya informasi yang ada. Bagaimana jika informasi yang dicari tidak ada di perpustakaan? maka dibutuhkan kreativitas dan pemahaman pustakawan terkait alternatif penelusuran informasi baik itu dari internet, perpustakaan lainnya, maupun dari sumber lain. Selanjutnya pustakawan sebagai konsultan informasi bukan hanya sebagai penunjuk letak sumber informasi, tapi juga harus menunjukkan arah informasi yang dibutuhkan pemustaka. Maksudnya pustakawan harus menguasai berbagai subjek. Hal tersebut dilakukan untuk dapat mempermudah proses penyelesaian masalah, ketepatan jawaban, dan, juga sebagai bentuk aplikasi diri terhadap profesionalisme dan memperbaiki citra perpustakaan. Jika perpustakaan khusus, maka biasanya subjek kajiannya terkait organisasi naungannya. Dengan penguasaan terhadap subjek tertentu, pustakawan dapat memberikan alternatif topik dan bahasan yang mungkin tidak terpikir oleh pencari informasi tersebut. Namun sekali lagi, dibutuhkan kemampuan penguasaan materi secarang luas dan komprehensif.

Dengan memberikan layanan konsultasi dan bimbingan subjek kepada pemustaka, diharapkan hubungan pustakawan dan pemustaka tidak hanya sebatas penyedia informasi dan pengguna informasi, tapi juga sebagai partner dalam menemukan informasi. Ketika menjadi partner bagi pemustaka, pustakawan memberikan pelayanan terbaiknya dengan menempatkan diri sebagai pemustaka yang mempunyai masalah informasi. Kelas Menulis Pustakawan (2017: 334) mengatakan bahwa dengan memberikan rasa simpati penuh dan solusi terhadap permasalahan yang dihadapi pemustaka, khususnya dalam hal pemenuhan kebutuhan informasi untuk pendidikan dan penelitian. Solusi yang dimaksud adalah pustakawan tidak hanya menyediakan literatur yang ada, tetapi juga mampu menjelaskan tentang bagaimana membaca, menyeleksi, dan menggunakan setiap jenis bahan 
bacaan referensi dengan tepat dan efisien. Dengan usaha pustakawan meningkatkan kualitas pelayanan yang prima menunjukkan bahwa profesionalisme pustakawan tidak hanya berorientasi pada pemahamannya akan dunia kepustakawanan, tetapi juga perlu memahami karakteristik dan kebutuhan informasi pemustaka. Jika pustakawan hanya puas dengan dunia teknis perpustakaan, maka perpustakaan tidak akan mendapatkan tajinya dalam masyarakat yang mempunyai paradigma yang salah tentang perpustakaan.

\section{Subject Guide sebagai Bentuk Profesionalisme}

Subjek guide merupakan panduan bagi pemustaka untuk lebih mudah memahami suatu subjek. Subjek guide ini berisi sumber informasi yang terdapat di perpustakaan baik berupa OPAC, nama ejurnal,institutional repository, link website, statistic, pemetaan bidang ilmu dimana semua sumber informasi tersebut fokus pada suatu bidang tertentu. Manfaat Subject Guide ini dapat memberikan referensi atau bahan rujukan informasi untuk para peneliti, kalangan akademisi, maupun masyrakat luas yangmembutuhkan informasi. Subject guide hadir sebagai penengah kondisi pemustaka saat ini yang memiliki kendala dalam masalah pengaksesan informasi yang mencakup pencarian dan penyebaran informasi (Laksmi, 2016: 40). Pustakawan sebagai aktor utama dalam layanan penelusuran informasi perpustakaan harus mempunyai strategi khusus dalam membantu pemustakanya dengan memanfaatkan koleksinya sebaik mungkin. Banyaknya koleksi, data yang tidak sesuai kondisi koleksi, dan kurangnya pelayanan sesuai dengan kebutuhan pemustaka membuat masyarakat informasi khususnya para akademisi akan mengalami kesulitan dalam menemukan informasi yang sesuai dengan objekpenelitian tersebut.

Produk berupa subject guide merefleksikan bahwa pustakawan berusaha untuk memberikan layanan sebaik mungkin dan sebagai cerminan dari profesionalisme pustawan itu sendiri. Diharapkan adanya produk ini dapat menjadikan citra positifbagi perpustakaan, karenaperpustakaan telah memberikan inovasi layanan jasa dengan mengembangkanteknologi informasi di perpustakaan, sehingga dapat dijadikan sebagai tolak ukurbagi pustakawan dalam memajukan kualitas layanan jasa bagi pemustaka dan jugadapat dijadikan sebagai motivasi bagi pustakawan agar mampu bersaing dengandunia luar untuk menghasilkan produk jasa layanan informasi yang dapat diaksesoleh pemustaka baik didalam maupun diluar perpustakaan (Nugrahayu, 2017: 6).

Profesionalisme merupakan suatu pemahaman yang menciptakan dilakukannya kegiatan kerja tertentu dalam masyarakat, berbekalkan keahlian yang tinggi dan berdasar rasa keterpanggilan, serta ikrar untukmenerimapanggilan tersebut, untuk dengan semangat pengabdian selalusiapmemberikan pertolongan kepada sesama yang dirundung kesulitanditengahgelapnya kehidupan (Siregar, 2016). Subject guide berisi konten yang terdiri dari berbagai macam informasi dan referensi yang dapat memandu pemustaka bertemu dengan informasi yang diinginkannya. Dalam penyusunannya dibutuhkan waktu dan analisis secara seksama dalam rangka sesuai dengan ekspektasi pemustaka dan benar-benar dapat memaksimalkan penggunaan subject guide. Dengan menganalisis dan menentukan topik yang akan dibuat panduannya, serta menyesuaikan dengan keadaan lapangan 
perpustakaan, dan selanjutnya memberikan alternative referensi menunjukkan bahwa dalam profesionalisme pustakawan juga dibutuhkan berpikir secara mendalam, tidak hanya melakukan sesuatu yang bersifat teknis dan monoton. Seorang pustakawan profesional pada perpustakaan perguruan tinggi harus selaluberusaha menghasilkan karya yang berkualitas tinggi dan kinerja yang terbaik dan maksimal (excellent) dengan terus mencoba memberikan dan mengerjakan lebih dari apa yang diharapkan (Santos, 2015).

Sekarang berkembang subject guide online yang lebih memudahkan pemustaka dalam penelusuran informasi ilmiah. Berbeda dengan subject guide berbentuk fisik. Subject guide yang disediakan secara online dapat memberikan akses yang lebih cepat dan kapanpun kepada pemustaka serta dalam satu laman dapat menampung lebih banyak subject guide dari pada harus menjejerkannya di rak yang kemungkinan tidak terlihat oleh pemustaka. Di Indonesia sendiri, subject guide online masih belum diterapkan di semua jenis perpustakaan. Masalah ini perlu dikaji lebih lanjut kenapa perpustakaan di Indonesia tidak mencatumkan laman subject guide di websitenya, karena betapa besar manfaat bagi pemustaka dan citra yang bisa didapatkan oleh pustakawan jika konten ini disediakan di laman website. Di Inggris sendiri beberapa perpustakaan universitas dan perpustakaan publik telah menerapkan subject guide online dalam penelusuran informasinya. Tidak hanya itu, institusi kearsipan dari perguruan tinggi tersebut juga menyediakan subject dalam penelusuran konten. Sebut saja Queen Mary University, University of York, Bodleian Libraries-University of Oxford, dan masih banyak lainnya. Adapun websitenya adalah sebagai berikut:

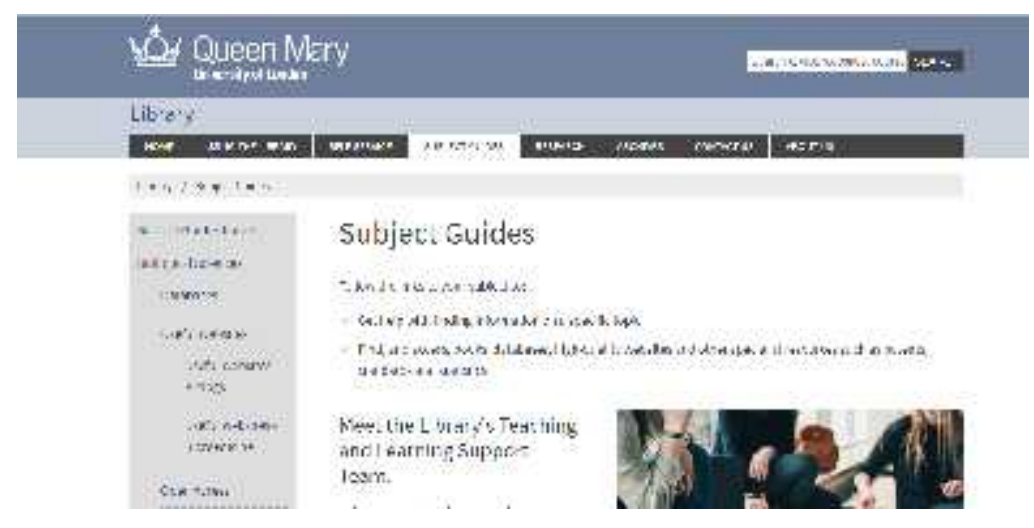

Gambar 1. Library of Queen Mary University of London (www.library.qmul.ac.uk/subject-guides/) 


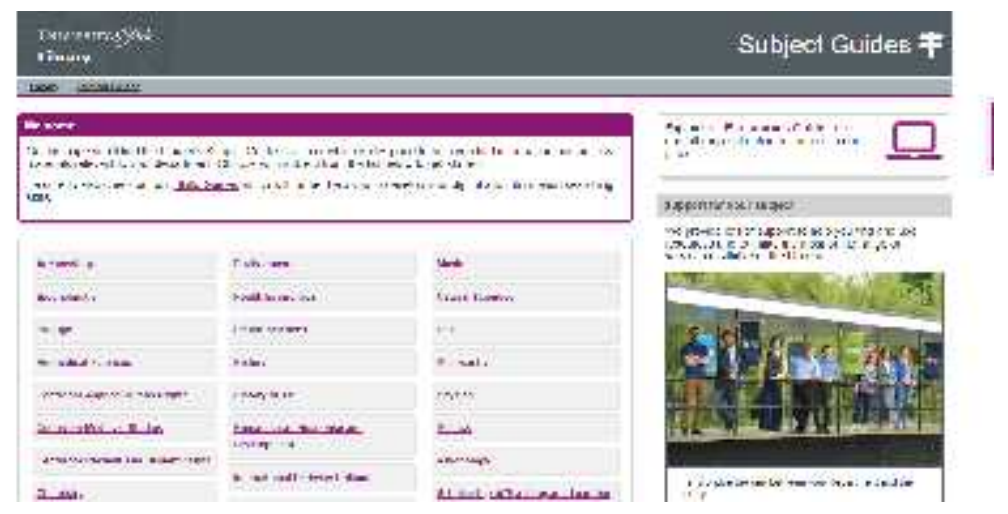

Gambar 2. Library of University of York (www.subjectguides.york.ac.uk/subjectguides)

Gambar di atas menunjukkan bahwa kedua perpustakaan tersebut berusaha untuk memberikan panduan terbaiknya kepada pemustaka dalam menemukan informasi yang dibutuhkan. Seperti salah satu tujuan dari subject guide Perpustakaan University of York dan Perpustakaan Queen Mary University of London yaitu membantu pemustaka mengembangkan kemampuan literasi informasi, menemukan informasi, menggunakan informasi tersebut secara efektif, mengembangkan kemampuan berpikir kritis, management dan sharing informasi. Subject guide di website perpustakaan universitas tersebut mempunyai berbagai disiplin ilmu, dari biologi sampai dengan psikologi.

Dalam menunjukkan profesionalisme kerja, pustakawan harus lebih berpikir luas dan kreatif. Paradigma teknis dan kepustakawanan sekarang harus berubah karena faktor teknologi informasi dan kebutuhan masyarakat yang berdinamika. Peningkatan personal skill, pengembangan kemampuan diri, serta mempunyai kemampuan tambahan di bidang lain yang mendukung kegiatan perpustakaan merupakan bentuk dari kegigihan dalam memberikan pelayanan terbaik dan sebagai bentuk profesionalisme pustakawan. Pustakawan tidak akan bergerak dari paradgima yang ada jika masih nyaman dengan zona kepustakawanan saja. Pustakawan yang memegang informasi mutakhir di perpustakaan juga harus perlu beradaptasi dengan dunia secara global.

\section{Simpulan}

Kelanjutan profesionalisme pustakawan dalam layanan penelusuran informasi adalah pustakawan harus memberikan opsi yang kreatif seperti penyediaaan subject guide dan juga dapat memahami kebutuhan pemustaka dengan menunjukkan profesionalismenya secara nyata melalui produk pencarian dan temu kembali informasi. Konsultan informasi dan pembuatan subjek guide merupakan kombinasi yang tepat dalam mengantarkan pemustaka kepada informasi yang dibutuhkan. Adanya kebutuhan informasi yang bersifat dinamis diharapkan perpustakaan dapat mantap berdiri sebagai pusat infomasi masyarakat melalui kompetensi pustakawannya. Akhirnya profesionalisme pustakawan itu benar-benar dapat dirasakan dan dilihat secara langsung melalui 
layanan yang diberikan sesuai kebutuhan pemustaka dengan tujuan memberikan sarana terbaiknya kepada pemustaka dalam pencarian informasinya.

\section{Daftar Pustaka}

Canfield, Marie P. 1972. "Library Pathfinders”. Drexel Library Quarterly. January 1972, Volume 8 No. 1

Departemen Pendidikan dan Kebudayaan. 1989. Pola Pengembangan Sekolah Menengah Kejuruan Seutuhnya. Malang: Dinas Pendidikan dan Kebudayaan Malang.

Nugrahayu, Maria Widya. 2016. Pemanfaatan Subject Guide Dalam Mempermudah Penelusuran Informasi Penyakit Kanker, Surabaya: Perpustakaan STMIK Surabaya.

Pawit, M. Yusuf. 2010. Teori dan Praktik Penelusuran Informasi: information retrieval, Jakarta: Kencana.

Puspitasari, Dewi. 2015. "Mewujudkan Liason Librarian Dalam Perpustakaan Perguruan Tinggi”, Acarya Pustaka Volume 1, No. 1, 50-62

Qalyubi, Syihabuddin. 2007. Dasar-dasar Ilmu Perpustakaan dan Informasi. Yogyakarta: Jurusan Ilmu Perpustakaan dan Informasi Fakultas Adab.

Santos, Hari. 2015. Profesi dan Profesionalisme Pustakawan Pada Perpustakaan Perguruan Tinggi, diakses dari, www.library.um.ac.id/index.php/Artikel-Pustakawan/profesi-dan profesionalismepustakawan-pada-perpustakaan-perguruan-tinggi.html

Siregar, Muhammad Riandy Arsin. 2015. "Kompetensi Yang Harus Di Miiliki Seorang Pustakawan (Pengelola Perpustaakaan)", Jurnal Iqra. Volume 09 No.02, 221-222

Suwarno, Wiji. 2013. Ilmu Perpustakaan dan Kode Etik Pustakawan. Yogyakarta: Ar-ruzz Media.

Tim Kelas Menulis Pustakawan. 2017. Inovasi Layanan Perpustakaan dan Fenomena Hoax. Surakarta: Yuma Pustaka.

Zed, Mestika. 2008. Metode Penelitian Kepustakaan. Jakarta: Yayasan Obor Nusantara. 